\title{
POTENSI WISATA BAHARI PULAU-PULAU KECIL DI KAWASAN KAPOPOSANG KABUPATEN PANGKEP
}

\author{
Marine Tourism Potential in Kapoposang Islands, Pangkep Regency
}

Oleh:

\author{
Krishna Samudra $^{1 *}$, Mulyono S. Baskoro ${ }^{2}$, Sugeng H. Wisudo ${ }^{2}$, dan Budhi H. Iskandar ${ }^{2}$ \\ ${ }^{1}$ Direktorat Jenderal Kelautan Pesisir dan pulau Kecil, Kementerian Kelautan dan Perikanan RI \\ 2 Departemen Pemanfaatan Sumber Daya Perikanan, FPIK, IPB, Jl. Lingkar Kampus, Darmaga - Bogor 16680 \\ *Korespondensi: samudrakrishna@yahoo.co.id
}

Diterima: 4 januari 2010; Disetujui: 30 Maret 2010

\begin{abstract}
Kapoposang area is located in Pangkep Regency consist of six small islands and consist of high marine and fisheries resources, especially the white sandy beaches and coral reefs within its ecosystem. This is an important factor for further development of marine tourism based on conservation. Identification of marine tourism resources is the first step in development planning process. Focus Group Discussion (FGD) and survei method was applied in this research. The result show that this area is a potential area to be developed as marine tourism area based on conservation consideration.
\end{abstract}

Key words: small islands, marine and fisheries resources, marine tourism

\section{ABSTRAK}

Kawasan Kapoposang di Kabupaten Pangkep merupakan gugusan pulau yang terdiri dari enam pulau-pulau kecil yang memiliki kelimpahan sumber daya kelautan dan perikanan, khususnya jasa lingkungan berupa keindahan pantai pasir putih dan terumbu karang beserta ekosistem asosiasinya, sebagai potensi yang sangat penting bagi pengembangan kawasan di masa depan, khususnya pembangunan kegiatan wisata bahari berbasis konservasi. Sebagai upaya untuk mendukung pengembangan kegiatan wisata bahari dimaksud, maka ketersediaan informasi tentang keragaan sumber daya di Kepulauan Kapoposang adalah suatu keharusan, mengingat hal tersebut merupakan informasi penting yang sangat membantu bagi para investor bidang wisata bahari untuk berinvestasi di pulau-pulau kecil Kawasan Kapoposang. Metode survei dan Focus Group Discussion (FGD) digunakan dalam penelitian ini. Hasil penelitian menunjukkan bahwa Kawasan Kapoposang memiliki potensi yang layak untuk dikembangkan sebagai daerah wisata bahari berazaskan konservasi.

Kata kunci: pulau-pulau kecil, keragaan sumber daya kelautan dan perikanan, wisata bahari

\section{PENDAHULUAN}

Kabupaten Pangkajene dan Kepulauan (Kabupaten Pangkep) merupakan kabupaten yang memiliki 114 pulau-pulau kecil dengan 90 pulau memiliki penduduk (berpenghuni) dan 24 kecil tidak berpenduduk (kosong), yang memiliki luas keseluruhan pulau kecil 35.150 ha, luas laut $71.000 \mathrm{~km}^{2}$, panjang garis pantai $250 \mathrm{~km}$, dan luasan terumbu karang $36.000 \mathrm{~km}^{2}$. Dari 114 pulau kecil yang dimiliki, enam pulau kecil diantaranya yaitu Pulau Kapoposang (berpenduduk), Pulau Gondongbali (berpenduduk), Pulau Papandangan (berpenduduk), Pulau Suranti (tidak berpenduduk), Pulau Tambakulu (tidak berpenduduk), dan Pulau Pamanggangan (tidak berpenduduk) berada dalam satu gugusan pulau, yaitu Kawasan Kapoposang.

Sesuai berita acara Departemen Kelautan dan Perikanan atau DKP No. BA.108/MEN. $\mathrm{KP} / \mathrm{III} / 2009$, pengelolaan Kawasan Kapoposang 
sebagai Taman Wisata Alam Laut (TWAL) telah beralih dari Departemen Kehutanan kepada Departemen Kelautan dan Perikanan (DKP) pada bulan Maret tahun 2009, yang dilanjutkan dengan dikeluarkannya Keputusan Bupati Pangkep Nomor 180 Tahun 2009 tentang Penetapan Kawasan Konservasi Laut Daerah Kabupaten Pangkep, dimana Kawasan Kapoposang diarahkan untuk pengembangan kegiatan wisata bahari berbasis konservasi. Kondisi dimaksud tentunya merupakan suatu peluang dan tantangan bagi daerah setempat, untuk mengembangkan Kawasan Kapoposang, khususnya untuk menarik investasi baik dari dalam maupun luar negeri. Namun karena pilihan pengelolaan sumber daya pulau-pulau kecil yang suistainable secara ekologis maupun ekonomi sangat terbatas, mengakibatkan pengembangan ekonomi hampir sulit dilakukan jika hanya mengandalkan kemampuan pulau untuk mengembangkan dirinya (self suffiency), sehingga membutuhkan adanya dorongan (big push) dan kepedulian (good political will) dari pihak luar, khususnya dunia usaha (investor). Berdasarkan kondisi dimaksud, maka dibutuhkan adanya suatu informasi mengenai kondisi sosial budaya masyarakat lokal serta keragaan sumber daya alam pulau-pulau kecil beserta karakteristiknya di Kawasan Kapoposang, khususnya dalam menunjang kegiatan wisata bahari berbasis konservasi yang akan dikembangkan di kawasan dimaksud.

Menurut Rais et al., (2004), konservasi yang berasal dari kata to conserve memiliki arti menyelamatkan, melindungi, melestarikan dan menyimpan, sehingga dalam konteks pengelolaan sumber daya alam konservasi berarti menghemat pemanfaatan sumber daya alam sehingga ketersediaanya selalu terjaga. Hal ini selaras dengan pengelolaan gugusan pulaupulau kecil di Kawasan Kapoposang yang berkelanjutan, yang memiliki arti bahwa pengelolaan dimaksud adalah suatu strategi pemanfaatan ekosistem alamiah yang sedemikian rupa, sehingga kapasitas fungsionalnya untuk memberikan manfaat bagi kehidupan manusia tidak rusak dan tetap terjaga.

Berdasarkan hal tersebut, perlu dikaji peluang pengembangan wisata bahari di kawasan Kepulauan Kapoposang dengan memanfaatkan potensi sumber daya alam yang ada dengan memperhatikan aspek konservasi. Tujuan dari kajian ini adalah mendeskripsikan potensi yang ada di Kawasan Kepulauan Kapoposan dan mendeskripsikan peluang pengembangan wisata bahari berazaskan konservasi.

\section{METODE PENELITIAN}

Penelitian dilakukan pada bulan September-Oktober 2009 di Kawasan Kapoposang, Kabupaten Pangkep, Sulawesi Selatan. Penelitian bersifat deskriptif dengan menggunakan teknik survei. Pengumpulan data primer dilakukan sebagai berikut: (1) pengamatan atau identifikasi langsung di lapangan untuk mengetahui dan memahami secara langsung kondisi eksisting pulau-pulau kecil di Kawasan Kapoposang meliputi kondisi fisik lokasi penelitian, kondisi ekonomi, sosial dan budaya masyarakat; dan (2) wawancara dan focus group discussion (FGD) dengan stakeholders Kabupaten Pangkep meliputi Bupati, Kepala Dinas dan Eselon III lingkup Dinas Kelautan dan Perikanan, Ketua Badan Perencanaan Pembangunan Daerah (Bappeda), Kepala Dinas Pariwisata, Kepala Dinas Lingkungan Hidup, Kepala Kantor Perizinan Satu Atap, Ketua Badan Koordinasi Penanaman Modal Daerah (BKPMD), tokoh masyarakat dan aga-ma di Kawasan Kapoposang. Pengumpulan data sekunder juga dilakukan dan diperoleh dari instansi pemerintah (Depertemen Kelautan dan Perikanan, Dinas Perikanan dan Kelautan serta instansi terkait), buku-buku pustaka, jurnal, dan sumber informasi lainnya.

\section{HASIL DAN PEMBAHASAN}

\section{Kondisi Umum}

Kawasan Kapoposang terdiri dari enam pulau yang secara administrasi merupakan bagian wilayah Kecamatan Liukang Tuppabiring yang terdiri dari dua desa, yaitu Desa Mattiro Ujung dan Desa Mattiro Mattae (Tabel 1).

Berdasarkan luas masing-masing pulau, maka Pulau: Kapoposang, Gondongbali, Papandangan, Suranti, Tambakulu, dan Pamanggangan adalah pulau kecil. Hal ini sesuai dengan yang dinyatakan dalam UU. No. 27 Tahun 2007 tentang Pengelolaan Wilayah Pesisir dan Pulau-pulau Kecil, bahwa yang dimaksud dengan pulau kecil adalah pulau dengan luas lebih kecil atau sama dengan $2.000 \mathrm{~km}^{2}$ (dua ribu kilometer persegi) beserta kesatuan ekosistemnya, yang pemanfataannya di sekitarnya diprioritaskan untuk salah satu atau lebih kepentingan sebagai berikut: (1) konservasi; (2) pendidikan dan pelatihan; (3) penelitian dan pengembangan; (4) budidaya laut; (5) pariwisata; (6) usaha perikanan dan kelautan dan industri perikanan secara lestari; (7) pertanian organik; dan/atau (8) peternakan. Wilayah Kawasan Kapoposang seperti disampaikan pada Gambar 1. 
Tabel 1. Wilayah Administrasi Kawasan Kepulauan Kapoposang

\begin{tabular}{|l|l|c|c|c|c|}
\hline Nama Desa & Nama Pulau & $\begin{array}{c}\text { Luas } \\
\text { Daratan } \\
\text { (ha) }\end{array}$ & $\begin{array}{c}\text { Luas } \\
\text { Terumbu } \\
\text { Karang (ha) }\end{array}$ & $\begin{array}{c}\text { Luas } \\
\text { Total } \\
\text { (ha) }\end{array}$ & $\begin{array}{c}\text { Berpenduduk/ } \\
\text { Kosong } \\
\text { (Jiwa) }\end{array}$ \\
\hline Mattiro Ujung & - Kapoposang & $-42,05$ & $-405,7$ & $-447,75$ & -484 \\
& - Papandangan & $-6,69$ & $-61,72$ & $-68,41$ & -853 \\
\hline Mattiro & - Gondongbali & $-5,28$ & $-54,92$ & $-60,21$ & -1.171 \\
Mattae & - Suranti & $-2,01$ & $-94,72$ & $-96,74$ & - Kosong \\
& - Tambakulu & $-1,81$ & $-78,77$ & $-10,19$ & - Kosong \\
& - Pamanggangang & $-1,74$ & $-0,157$ & $-80,52$ & - Kosong \\
\hline
\end{tabular}

Sumber: Dinas Kelautan dan Perikanan Kabupaten Pangkep, 2007

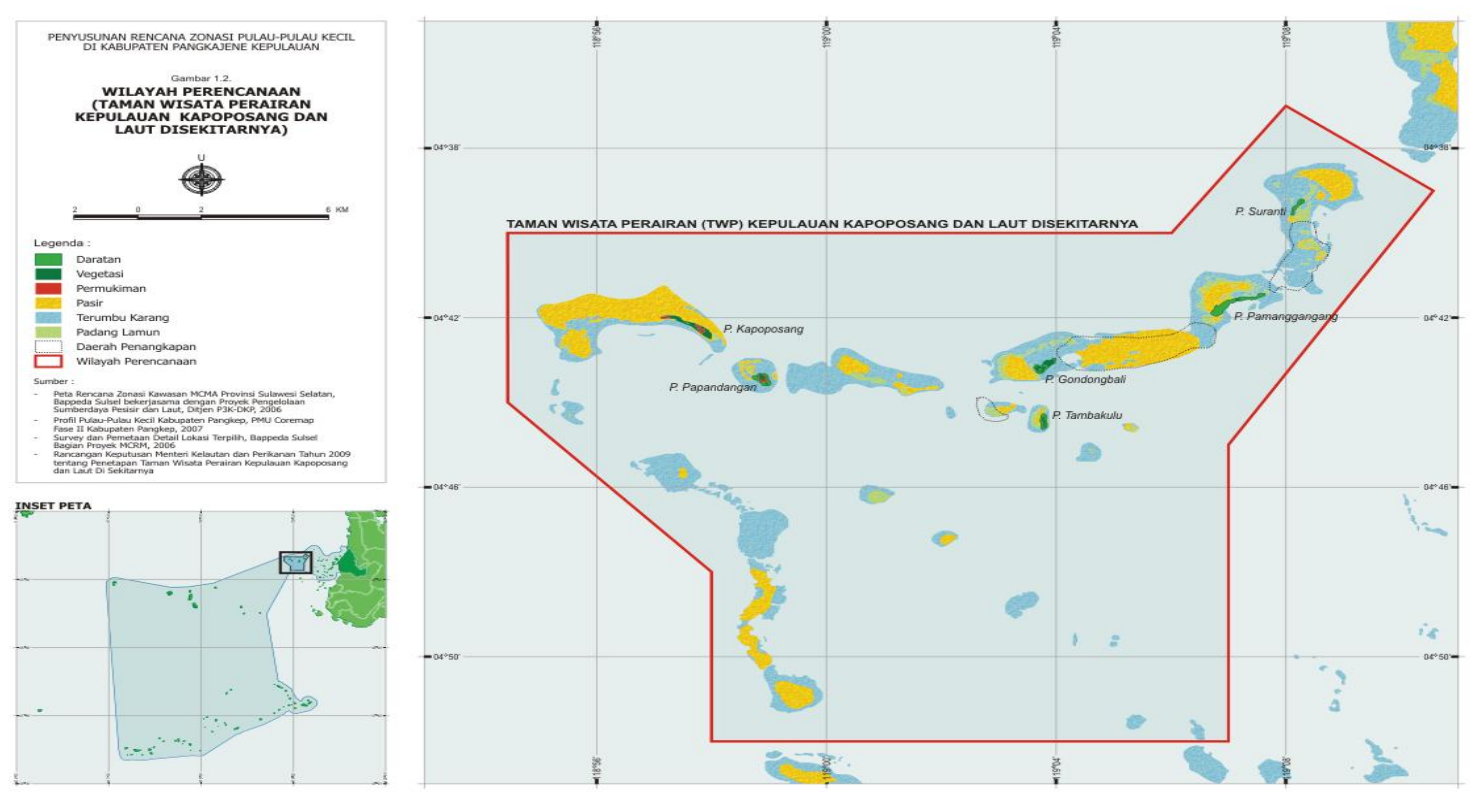

Gambar 1. Wilayah Kawasan Kapoposang (Sumber DKP, 2009).

Keenam pulau di kawasan Kapoposang memiliki karakteristik pengembangan khas pulau-pulau kecil, seperti yang dinyatakan oleh Retraubun (2005), bahwa beberapa karakteristik pulau-pulau kecil yang dapat menjadi kendala pengembangannya antara lain adalah: (1) ukuran yang kecil dan terisolasi menyebabkan sangat mahalnya sarana dan prasarana, serta minimnya sumber daya manusia yang handal; (2) kesulitan atau ketidakmampuan untuk mencapai skala ekonomi yang optimal dan menguntungkan (dalam hal administrasi, usaha produksi, dan transportasi); (3) ketersediaan sumber daya alam dan jasa-jasa lingkungan yang ada pada akhirnya akan menentukan daya dukung suatu sistem pulau-pulau kecil dalam menopang kehidupan manusia dan kegiatan pengembangannya; (4) produktivitas sumber daya alam dan jasa-jasa lingkungan yang ada saling terkait satu sama lain secara erat. Keberhasilan usaha pertanian, perkebunan atau kehutanan di lahan darat yang melupakan prinsip-prinsip ekologis, dapat mengakibatkan kematian/kerusakan pada industri perikan- an pantai dan pariwisata bahari di pulau-pulau kecil; dan (5) budaya lokal yang kadangkala bertentangan dengan kegiatan pembangunan (terutama pariwisata), karena budaya wisatawan (asing) yang tidak sesuai dengan adat atau agama setempat.

Pulau-pulau kecil di Kawasan Kapoposang meskipun memiliki sumber daya alam daratan (teresterial) yang terbatas, namun memiliki potensi sumber daya kelautan dan perikanan yang melimpah sebagai aset yang strategis dan komparatif yang dapat menjadi aset kompetitif dalam mengisi pembangunan daerah. Pulau-pulau kecil pada dasarnya membutuhkan pengelolaan yang bertitik tolak dari kekhususan yang menjadi ciri khas pulau kecil tersebut, yaitu kondisi sumber daya alam (hayati dan nir hayati), sumber daya manusia (kondisi sosial, ekonomi dan budaya masyarakat lokal), serta jasa-jasa lingkungan seperti misalnya kegiatan pariwisata, khususnya wisata bahari. Pitana dan Gayatri (2005) menyatakan, bahwa bagi negara-negara di Kepulauan Kari- 
bia kegiatan wisata bahari merupakan penyumbang terbesar dalam penciptaan pendapatan masyarakat dan negara. Kegiatan wisata bahari telah menciptakan 2,5 juta kesempatan kerja atau sekitar $25 \%$ dari total kesempatan kerja pada tahun 2001, serta menyumbang sekitar US\$ 9,2 milyar atau sekitar 5,8\% dari total GDP Kepulauan Karibia. Bagi negara Fiji (sebuah negara pulau di Samudra Pasific), pada tahun yang sama, kegiatan wisata bahari bahkan menjadi penghasil devisa kedua, yaitu sekitar $35 \%$ dari total nilai ekspor negara ini, dan hanya sedikit di bawah hasil utamanya yaitu gula dan hasil pertanian lainnya.

Kementerian Kebudayaan dan Pariwisata (2004), menyatakan bahwa pengelolaan wisata bahari di pulau-pulau kecil harus berpegang pada prinsip-prinsip dasar sebagai berikut: (1) prinsip keseimbangan, yaitu pengelolaan harus didasarkan pada komitmen pola keseimbangan antara pembangunan ekonomi, sosial, budaya dan konservasi; (2) prinsip partisipasi dan pelibatan masyarakat lokal; (3) prinsip keterpaduan, yaitu pengelolaan yang harus direncanakan secara terpadu dengan memperhatikan ekosistem pulau luar dan disinerjikan dengan pembangunan berbagai sektor; (4) prinsip penegakan hukum, yaitu pengelolaan yang sesuai dengan aturan-aturan hukum yang ada, serta dilaksanakan dengan penegakan hukum maupun peraturan yang berlaku untuk menjamin kepastian hukum; dan (5) prinsip konservasi, yaitu pengelolaan yang harus memiliki kepedulian, tanggung jawab dan komitmen terhadap pelestarian lingkungan (alam dan budaya), sehingga dalam pengelolaannya diselenggarakan secara bertanggung jawab, mengikuti kaidah-kaidah ekologi, peka dan menghormati nilai-nilai sosial-budaya dan tradisi keagamaan masyarakat setempat, serta sesuai dengan daya dukung yang ada.

Daya dukung Kawasan Kapoposang dimaksud antara lain meliputi:

1) Daya dukung ekologi. Terumbu karang di sekitar Kawasan Kapoposang dengan kondisi baik dijumpai pada kedalaman 12-14 m dengan presentase tutupan karang hidup berkisar sekitar $60 \%$. Kondisi sangat baik dijumpai pada kedalaman 4-10 m dengan kisaran presentase tutupan karang hidup berkisar $80 \%$ hingga $90 \%$. Potensi ini dapat dimanfaatkan sebagai gudang dari plasma nutfah, nursery ground (daerah asuhan), spawning ground (daerah berbiak), feeding ground (daerah mencari makanan), dan menjadi tujuan utama bagi para wisatawan penikmat keindahan terumbu karang (coral reefs). Hal ini didukung dengan keanekara- gaman jenis karang yang cukup tinggi dari Pulau Kapoposang hingga Pulau Suranti. Disamping itu persen penutupan terumbu karang berkisar antara 50\%-70\%, dengan genera yang umum dijumpai antara lain jenis Fungia sp, Montipora sp, Hydnopora $\mathrm{sp}$, Porites sp, Acropora sp, dan Sponge sp. Menurut Berhimpon et al., (2007), sebaran terumbu karang beserta asosiasinya di perairan pulau-pulau kecil umumnya memiliki nilai keanekaragaman sekitar 50\%-70\%, yaitu suatu kondisi yang relatif masih baik dengan indikasi masih banyaknya dijumpai ikan indikator dari famili Chaetodontidae, komunitas ikan karang yang berasosiasi dengan terumbu karang yakni, Pomacentridae, Scaridae, Caesionidae, Siganidae, dan Lutjanidae, serta ditemukannya Tridacnide (kima) dan seagrasses. Lebih lanjut dinyatakan oleh Yusuf (2008), bahwa mengingat pentingnya keles-tarian terumbu karang bagi kelangsungan hidup organisme yang berasosiasi langsung atau tidak langsung dalam menyokong kehidupan manusia, maka upaya pemerintah daerah dengan memasukkan suatu kawasan perairan pulau-pulau kecil menjadi Kawasan Konservasi Laut Daerah merupakan tindakan yang sangat mendukung bagi upaya konservasi terumbu karang serta jenis ikan dan biota yang berasosiasi di dalamnya. Hal ini juga dimaksudkan untuk menengahi persoalan kerusakan ekosistem terumbu karang dan kebutuhan hidup masyarakat pulau menjadi kawasan yang lebih baik.

2) Daya dukung sosial budaya. Masyarakat di tiga pulau, yaitu Pulau Kapoposang, Pulau Papandangan dan Pulau Gondongbali, relatif tergolong masyarakat nelayan subsisten (pendapatan yang diperoleh hanya dapat mencukupi kebutuhan makan sehari-hari). Namun hal tersebut tidak menghalangi kesadaran untuk melakukan upaya preservasi ekologi terumbu karang dengan menghindari kegiatan penangkapan ikan yang cenderung merusak dan ilegal. Meskipun pola kekerabatan dan lembaga adat kurang berkembang, permasalahan yang timbul dalam kehidupan sosial kemasyarakatan dibahas dan diselesaikan melalui rembug desa. DKP (2009) menyatakan, bahwa pelibatan masyarakat secara langsung dalam proses penetapan zonasi, pelaksanaan kegiatan pengawasan dan pengembangan kegiatan pariwisata ke depan menjadi sangat penting, untuk meyakinkan bahwa pembagian zonasi tidak dimaksudkan untuk membatasi usaha masyarakat, namun dapat meningkatkan kesejahteraan melalui pengembangan kegiat- 
an-kegiatan wisata bahari berbasis konservasi;

3) Daya dukung ekonomi. Kawasan Kapoposang memiliki keanekaragaman hayati yang sangat tinggi, sehingga dapat menjadi sumber plasma nuftah serta pemanfaatan jasa-jasa lingkungan sebagai objek wisata bahari yang bernilai ekonomis sangat tinggi. Menurut DKP (2007), konsep wisata bahari berbasis konservasi didasarkan kepada fenomena keunikan alam, karakteristik ekosistem terumbu karang, kekhasan budaya, dan karakteristik masyarakat nelayan. Jenis wisata bahari yang dapat dikembangkan antara lain berjemur (sunbathing), berenang (swimming), berperahu (boating), memancing (fishing), snorkling, menyelam (diving), wisata budaya, wisata riset, serta wisata dengan minat khusus seperti wisata pengamatan penyu bertelur dengan pasar khusus bagi orang-orang yang sadar akan lingkungan dan tertarik untuk mengamati alam atau berbasis konservasi.

Konservasi wilayah pesisir dan pulau-pulau kecil adalah upaya perlindungan, pelestarian dan pemanfaatan wilayah pesisir dan pulaupulau kecil serta ekosistemnya untuk menjamin keberadaan, ketersediaan, dan kesinambungan sumber daya pesisir dan pulaupulau kecil dengan tetap memelihara dan meningkatkan kualitas nilai dan keanekaragamannya. Menurut DKP (2005), kawasan konservasi di wilayah pesisir dan pulaupulau kecil adalah kawasan pesisir dan pulau-pulau kecil dengan ciri khas tertentu yang dilindungi untuk mewujudkan pengelolaan wilayah pesisir dan pulau-pulau kecil secara berkelanjutan, yang dibagi atas tiga zona yaitu: (1) zona inti yang merupakan bagian dari kawasan konservasi di wilayah pesisir dan pulau-pulau kecil yang dilindungi, yang ditujukan untuk perlindungan habitat dan populasi sumber daya pesisir dan pulau-pulau kecil serta pemanfaatannya hanya terbatas untuk penelitian; (2) zona pemanfaatan terbatas yang merupakan bagian dari zona konservasi pesisir dan pulau-pulau kecil yang pemanfaatannya hanya boleh dilakukan untuk budidaya pesisir, ekowisata, dan perikanan tradisional; dan (3) zona lain sesuai dengan peruntukkan kawasan. Berdasarkan kondisi dimaksud, maka dibutuhkan adanya rencana pembagian zonasi berdasarkan potensi masingmasing pulau di Kawasan Kapopo-sang.

\section{Rencana Pembagian Zonasi}

Kawasan Kepulauan Kapoposang berdasarkan konsultansi publik yang dilakukan oleh DKP (2009), termasuk dalam rencana zonasi pulau-pulau kecil di Kabupaten Pangkep dengan pembagian zonasi sebagai berikut (Gambar 2).

1) Zona inti di Selatan Pulau Kapoposang dan Utara Pulau Suranti, yang diperuntukkan bagi aktivitas perlindungan mutlak habitat dan populasi ikan, penelitian, dan pendidikan.

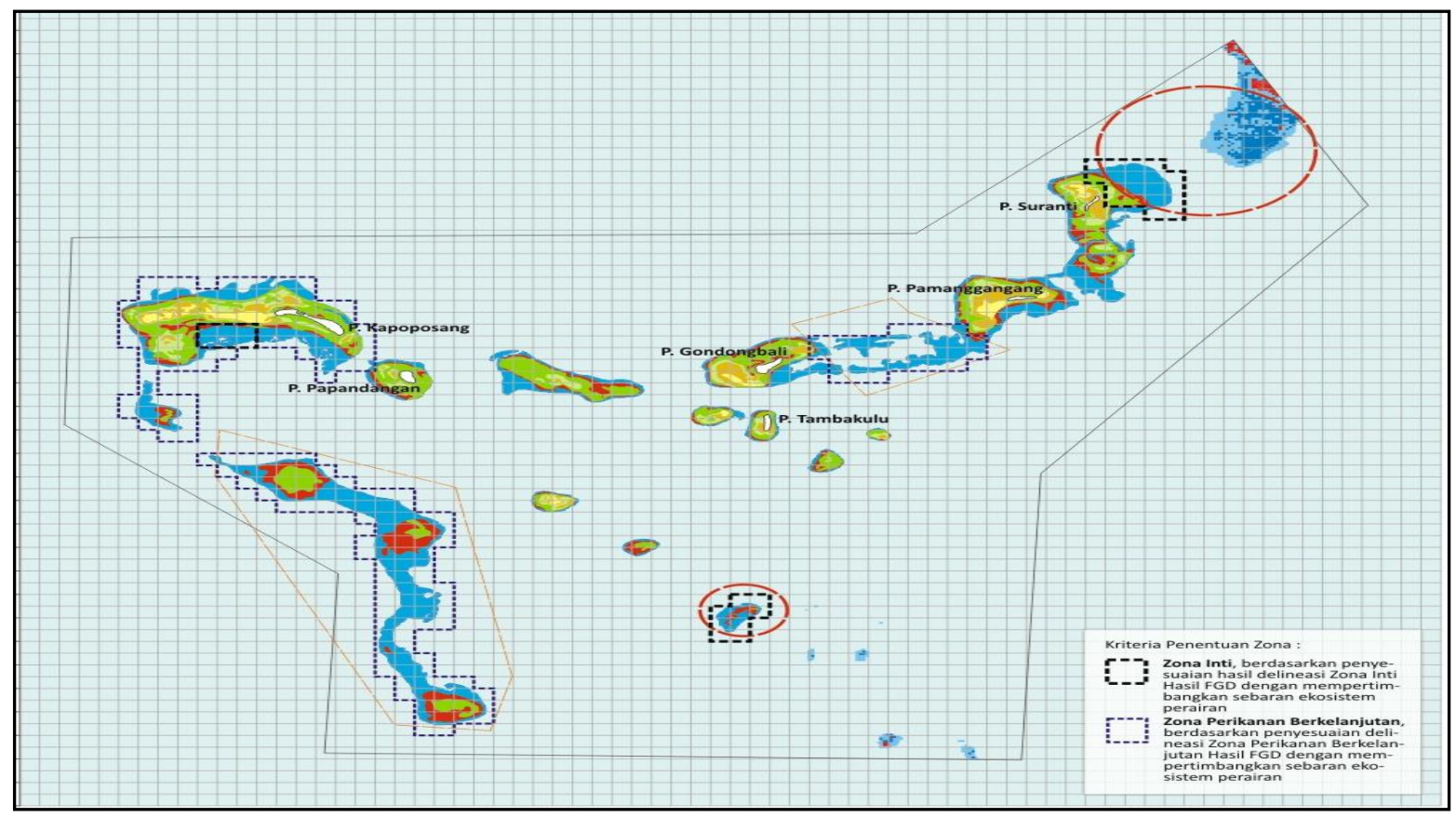

Gambar 2. Kesesuaian Zonasi Kawasan Kapoposang (Sumber DKP, 2009). 
2) Zona perikanan berkelanjutan di antara Pulau Gondongbali dan Pulau Pamanggangang, yang diperuntukkan bagi aktivitas: perlindungan habitat dan populasi ikan, penangkapan ikan dengan alat dan cara yang ramah lingkungan, budidaya ramah lingkungan, pariwisata dan rekreasi, penelitian dan pengembangan, serta pendidikan.

3) Zona pemanfaatan terbatas yang diperuntukkan bagi aktivitas: perlindungan habitat dan populasi ikan, pariwisata dan rekreasi, penelitian dan pengembangan, serta pendidikan.

4) Zona lainnya merupakan zona di luar zona inti, zona perikanan berkelanjutan, dan zona pemanfaatan yang fungsi dan kondisinya ditetapkan sebagai zona tertentu antara lain: zona perlindungan, zona rehabilitasi, dan zona peruntukkan lainnya.

Berdasarkan pembagian zonasi dimaksud, maka kegiatan wisata bahari berbasis konservasi di gugusan pulau-pulau kecil di Kawasan Kapoposang dapat menjadi alternatif prioritas utama pengembangan karena memiliki efek ganda (multiplier effect) bagi peningkatan kesejahteraan masyarakat, pelestarian lingkungan, serta merupakan aktivitas yang memenuhi segenap kriteria pembangunan berkelanjutan. Menurut Retrau-bun (2003), pembangunan pulau-pulau kecil berkelanjutan adalah pengelolaan pulau-pulau kecil yang harus memenuhi segenap kriteria secara ekonomi efisien dan optimal (economically sound), secara sosialbudaya berkeadil-an dan dapat diterima (socioculturally acepted and just), dan secara ekologis tidak melampaui daya dukung lingkungan (enviromentally friendly). Sektor wisata bahari mempunyai keunikan tersendiri dibanding dengan sektor-sektor lainnya, karena secara sederhana, sektor pariwisata dapat diklasifikasikan sebagai kegiatan ekspor, dalam artian bahwa income atau devisa yang diperoleh adalah melalui resources yang dimiliki oleh masyarakat dari negara lain (wisatawan asing), atau masyarakat dari daerah lain (wisatawan nusantara). Uniknya, kegiatan ekspor dimaksud, tidak menimbulkan biaya ataupun fee yang dikeluarkan oleh negara (lazimnya seperti kegiatan perdagangan komoditas dan barang), dan hampir sebagian besar biaya yang timbul akan diterima oleh negara yang merupakan tempat tujuan wisata tersebut. Bila dilihat dari segi perilaku (behaviour), kegiatan wisata bahari adalah kegiatan yang bersifat konsumtif, dalam artian bahwa seseorang ataupun lembaga memang sengaja mengumpulkan uang untuk kemudian menghabiskannya dengan tujuan menikmati objek-objek wisata. Oleh karena itu, tranksaksi dan multiflier effect yang terjadi dalam sektor wisata bahari merupakan transaksi dengan omset yang relatif tinggi mencapai triliunan rupiah (Retraubun, 2006).

Pengembangan sektor wisata bahari berbasis konservasi di gugusan pulau-pulau kecil di Kawasan Kapoposang dapat menjadi harapan sebagai salah satu sektor yang diandalkan dalam menopang pembangunan ekonomi kawasan, daerah dan juga nasional. Menurut DKP (2006), wisata bahari (marine tourism) dapat menjadi program utama dalam: (1) memulihkan kerusakan sumber daya laut, pesisir dan pulau-pulau kecil, (2) mengembalikan peranan masyarakat untuk ikut serta dalam menjaga kelestarian lingkungan, serta (3) berperan dalam menyumbangkan devisa bagi negara dan bagi peningkatan pendapatan asli daerah (PAD) dan devisa negara.

Kembudpar (2004), menyatakan bahwa wisata bahari merupakan jenis wisata minat khusus yang memiliki aktivitas yang berkaitan dengan kelautan, baik di atas permukaan laut (marine) maupun kegiatan yang dilakukan di bawah permukaan laut (sub marine). Wisata minat khusus sendiri adalah suatu bentuk perjalanan wisata, di mana wisatawan mengunjungi suatu tempat karena memiliki minat atau tujuan khusus mengenai sesuatu jenis obyek atau kegiatan yang dapat ditemui atau dilakukan di lokasi atau daerah tujuan wisata tersebut. Ekowisata bahari adalah penyelenggaraan kegiatan wisata bahari berbasis konservasi yang bertanggung jawab di daerah lingkungan laut yang masih alami dan/atau daerah-daerah yang dibuat berdasarkan kaidah alam, yang mendukung upaya-upaya pelestarian lingkungan (alam dan kebudayaan), bermuatan pendidikan dan pengajaran, serta dapat meningkatkan kesejahteraan masyarakat setempat.

Kegiatan perikanan tangkap ramah lingkungan dapat menjadi salah satu atraksi wisata bahari di kawasan Kapoposang, yaitu berupa sport fishing sebagai bagian dari rekreasi air. Kembudpar (2004) menyebutkan bahwa obyek wisata bahari diantaranya meliputi: (1) wisata selam (diving dan snorkling) yang menekankan pada usaha kegiatan penyediaan sarana, fasilitas atau jasa pemanduan untuk penjelajahan alam bawah air; (2) wisata marina yang merupakan kegiatan usaha berupa penyediaan tempat berlabuh dan tambatnya kapal-kapal pesiar, kapal layar atau lainnya; dan (3) rekreasi air yaitu kegiatan usaha penyediaan sarana dan prasarana di perairan laut, pantai atau pesisir seperti lomba memancing, selancar, ski air dan berenang. 
Berdasarkan kondisi di atas, dapat dikatakan bahwa kegiatan wisata bahari berbasis konservasi di Kawasan Kapoposang akan memberikan banyak manfaat. Menurut DKP (2005), secara umum pemanfaatan jasa kelautan wisata bahari di pulau-pulau kecil melalui penetapan kawasan konservasi laut memberikan manfaat antara lain: (1) Ekonomi. Kawasan konservasi laut memiliki nilai ekonomis tinggi berupa kekayaan terumbu karang dengan segala bentuk asosiasi kehidupan bawah laut yang memiliki produktivitas dan keragaman jenis hayati yang tinggi, merupakan potensi wisata bahari yang dapat membantu meningkatkan pendapatan masyarakat lokal, pendapatan asli daerah dan devisa negara; (2) Ekologi. Kegiatan wisata bahari yang ramah lingkungan (berbasis konservasi) dapat menjaga keseimbangan kehidupan biota laut, menjaga hubungan timbal balik antara biota laut dan faktor abiotik, serta menjaga kepedulian manusia terhadap lingkungannya; (3) Estetika. Kawasan konservasi laut yang memiliki nilai keindahan sebagai daya tarik obyek wisata bahari merupakan kawasan yang potensial bagi pengembangan berbagai obyek yang menarik seperti Scuba Diving, Snorkelling, Sport Fishing, dan Sun Bathing (wisata berjemur); (4) Pendidikan dan penelitian. Wisata bahari di kawasan konservasi laut dapat berjalan secara harmonis dengan pengembangan dan peningkatan ilmu pengetahuan, pendidikan dan penelitian yang berkaitan dengan upaya-upaya pelestarian sumber daya hayati laut dan ekosistemnya; dan (5) Jaminan masa depan. Penetapan kawasan konservasi laut diharapkan memiliki jaminan untuk pemanfaatan sumber daya alam laut secara lestari dan berkesinambungan bagi kehidupan generasi kini dan men- datang, seiring kelangsungan usaha wisata bahari yang berkembang. Kusumastanto (2007) menyatakan bahwa Jika berhasil dikembangkan secara optimal dan berkelanjutan, pulaupulau kecil ini bukan saja akan menjadi sumber pertumbuhan baru, melainkan sekaligus akan mengurangi kesenjangan pembangunan antarwilayah dan kelompok sosial. Keragaan Pulau Kapoposang sebagai salah satu pulau berpenghuni di Kawasan Kapoposang seperti yang disebutkan pada Tabel 1.

Pulau Kapoposang memiliki luas rataan terumbu karang $\pm 995,6 \mathrm{Ha}$, yang memanjang ke arah barat. Rataan terumbu pada kedalaman 4-8 $\mathrm{m}$ berbatasan dengan tubir terumbu dan dinding terumbu (drop off) berada pada perairan yang sangat jernih, dengan kondisi tutupan karang hidup lebih dari $75 \%$ (Dinas KP Kab. Pangkep, 2007). Gambar 3 di bawah ini menunjukkan kondisi terumbu karang dan ikan karang di Pulau Kapoposang.

Terumbu karang di sisi selatan cukup landai yang didominasi oleh jenis karang Acropora sp dan Montipora sp dengan tipe pertumbuhan yang memanjang. Di sisi utara didominasi oleh jenis karang masif dan bercabang pendek seperti Pocillopora sp, Acropora sp, dan Porites sp. Kepadatan ikan karang indikator di sepanjang drop off sisi utara dan barat sekitar 1.360 ekor dalam $500 \mathrm{~m}^{2}$, yang meliputi jenis-jenis ikan dari famili Pomacentridae, Caesionidae, Siganidae, dan Lutjanidae, serta biota asosiasi terumbu karang seperti kipas laut (Gorgonian) dan kima (Tridacnide). Sementara itu, kondisi sarana dan prasarana di Pulau Kapoposang seperti disampaikan pada Tabel 2.

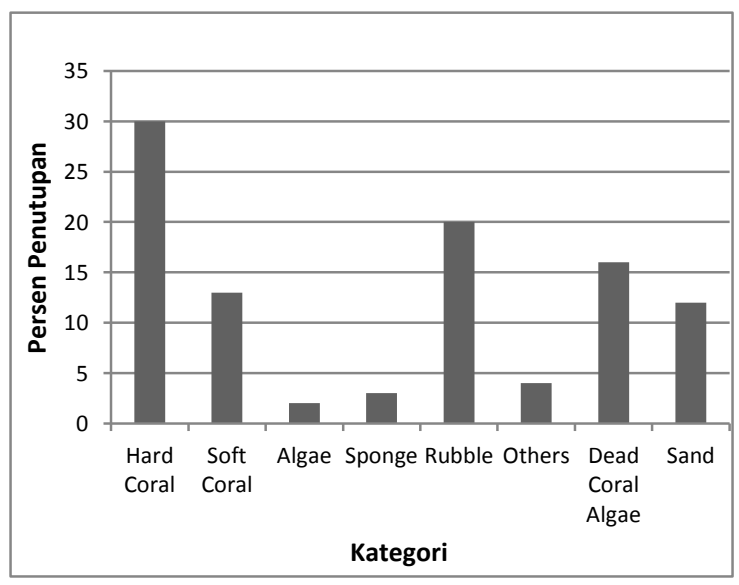

(a)

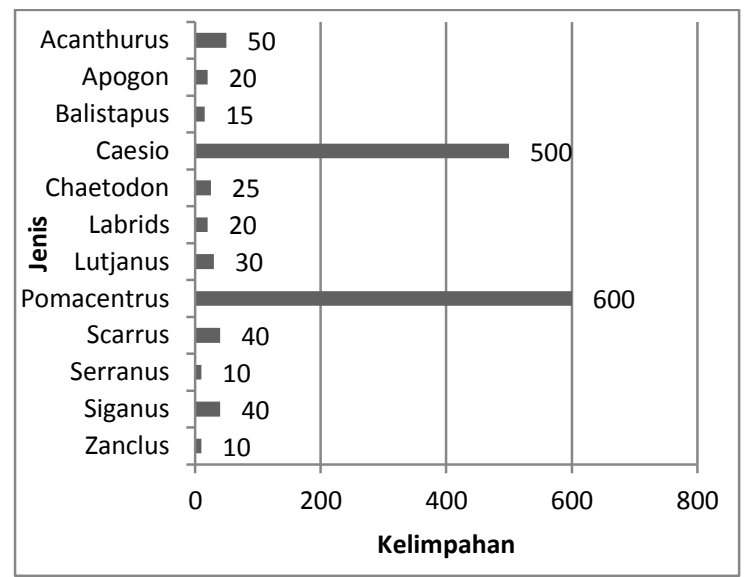

(b)

Gambar 3. Kondisi Terumbu Karang (a) dan Ikan Karang (b) di Pulau Kapoposang (Sumber Dinas Kelautan dan Perikanan Kab. Pangkep, 2007). 
Tabel 2. Sarana dan Prasarana di Pulau Kapoposang

\begin{tabular}{|c|c|c|c|c|}
\hline No. & $\begin{array}{c}\text { Jenis Sarana } \\
\text { dan Prasarana }\end{array}$ & Bentuk Fisik & Jumlah & Keterangan \\
\hline 1. & Pendidikan & Sekolah Dasar & 1 unit & $\begin{array}{l}\text { Kondisi gedung dan ruang } \\
\text { kelas membutuhkan } \\
\text { perbaikan }\end{array}$ \\
\hline 2. & Penerangan & $\begin{array}{l}\text { Generator berbahan } \\
\text { bakar solar dengan } \\
\text { kapasitas } 44 \mathrm{KVA}\end{array}$ & 1 unit & $\begin{array}{l}\text { Beroperasi pada pukul } \\
17.00-22.00 \text { WITA } \\
\text { Hanya mampu menyuplai } \\
\text { sebagian rumah warga }\end{array}$ \\
\hline 3. & Tambat kapal & $\begin{array}{l}\text { Darmaga/jetty dari kayu } \\
\text { dengan ukuran }(50 \times 2,5) \\
\text { meter }\end{array}$ & 1 unit & $\begin{array}{l}\text { Sebagai pelabuhan rakyat } \\
\text { baik untuk transportasi } \\
\text { maupun pendaratan ikan }\end{array}$ \\
\hline 4. & Jalan & Berupa jalan tanah & $4 \mathrm{~km}$ & Mengelilingi pulau \\
\hline 5. & Air bersih & $\begin{array}{l}\text { Sumur air minum } \\
\text { Sumur mencuci dan } \\
\text { mandi }\end{array}$ & $\begin{array}{l}7 \text { unit } \\
9 \text { unit }\end{array}$ & $\begin{array}{l}\text { Berlakunya aturan adat } \\
\text { dalam memanfaatkan } \\
\text { sumber air } \\
\text { Dimanfaatkan oleh } \\
\text { penduduk pulau } \\
\text { sekitarnya }\end{array}$ \\
\hline 6. & Wisata Bahari & $\begin{array}{l}\text { Losmen dengan } \\
\text { bangunan dari kayu }\end{array}$ & 5 unit & $\begin{array}{l}4 \text { unit milik Pemda dan } 1 \\
\text { unit milik swasta, yang } \\
\text { pengelolaannya } \\
\text { dikerjasamakan antara } \\
\text { Pemda dan pihak swasta }\end{array}$ \\
\hline 7. & $\begin{array}{l}\text { Tranportasi } \\
\text { darat }\end{array}$ & $\begin{array}{l}\text { Sepeda } \\
\text { Sepeda motor }\end{array}$ & $\begin{array}{l}37 \text { unit } \\
8 \text { unit }\end{array}$ & $\begin{array}{l}\text { Sepeda motor difungsikan } \\
\text { sebagai ojek }\end{array}$ \\
\hline 8. & Peribadahan & $\begin{array}{l}\text { Mesjid } \\
\text { Musholla }\end{array}$ & $\begin{array}{l}1 \text { unit } \\
1 \text { unit }\end{array}$ & $\begin{array}{l}\text { Difungsikan pula sebagai } \\
\text { TPA bagi anak-anak }\end{array}$ \\
\hline 9. & $\begin{array}{l}\text { Pendukung } \\
\text { perekonomian }\end{array}$ & $\begin{array}{l}\text { Toko/Kios } \\
\text { Koperasi }\end{array}$ & $\begin{array}{l}3 \text { unit } \\
1 \text { unit }\end{array}$ & $\begin{array}{l}\text { Milik masyarakat } \\
\text { KUD }\end{array}$ \\
\hline 10. & Kesehatan & Balai Pengobatan & 1 unit & $\begin{array}{l}\text { Dikelola } 1 \text { orang Bidan } \\
\text { dan } 1 \text { orang perawat }\end{array}$ \\
\hline 11. & Olahraga & Lapangan Bulu Tangkis & 1 unit & $\begin{array}{l}\text { Dikelola oleh Karang } \\
\text { Taruna }\end{array}$ \\
\hline
\end{tabular}

Sumber: Berdasarkan Data Olahan, 2009

Mata pencaharian sebagian besar warga adalah sebagai nelayan sub sisten (hanya cukup untuk memenuhi kebutuhan sehari-hari). Alat tangkap yang paling banyak digunakan adalah alat tangkap lanra (jaring insang monofilamen) dan mini trawl untuk menangkap kepiting dan udang. Pukat banyara digunakan untuk mencari ikan terbang dan pancing (kedokedo) digunakan untuk menangkap ikan-ikan karang. Lokasi penangkapan kepiting dan udang (dengan mini trawl) dan ikan terbang (dengan banyara) relatif dekat, yaitu di sekitar pulau tempat tinggal warga. Pemancingan ikan dilakukan oleh masyarakat ketika musim barat tiba, dimana ombak relatif besar, sehingga kegiatan penangkapan tersebut tidak dilakukan di lokasi yang jauh tetapi di daerah terumbu karang sekitar pulau dengan menggunakan pancing tradisional. Hasil yang didapatkan hanya diperuntukkan bagi pemenuhan konsum- si rumah tangga sehari-hari. Masa-masa paceklik terjadi pada musim barat, banyak nelayan yang tidak melaut karena kondisi perairan laut yang berombak tinggi. Berdasarkan kalender musim, kepiting dan udang paling melimpah masa penangkapannya, antara bulan Oktober dan Maret. Jenis tangkapan lainnya adalah ikan, seperti ikan banyara dan sunu. Beberapa nelayan juga adalah nelayan teripang. Penangkapan teripang ini tidak mengenal musim, sehingga hampir setiap hari dilakukan seskipun jumlahnya sedikit.

Selain pulau berpenghuni, Desa Mattiro Matae memiliki tiga pulau kosong (tidak berpenduduk) yang termasuk dalam kawasan pengelolaan kawasan Kepulauan Kapoposang, yaitu: (1) Pulau Pamanggangan dengan luas total (daratan dan sebaran terumbu karang) sekitar 80,52 ha; (2) Pulau Tambakulu dengan luas total (daratan dan sebaran terumbu ka- 
rang) sekitar 10,19 ha; dan (3) Pulau Suranti dengan luas total (daratan dan sebaran terumbu karang) sekitar 96,74 ha.

Ketiga pulau tersebut merupakan pulau yang menjadi tempat persinggahan nelayan, baik untuk bermalam maupun sekedar beristirahat. Disamping itu juga kerap digunakan sebagai tempat rekreasi pantai bagi para wisatawan lokal. Kondisi umum ketiga pulau memiliki hamparan pasir dengan terumbu karang yang relatif rusak (diduga akibat aktivitas pengeboman dan penggunaan racun sianida). Penutupan karang hanya sekitar 5-15\% karang hidup, yang didominasi oleh karang keras di sisi baratnya. Hamparan pasir dan karang (reef flat) cukup luas dan dangkal. Vegetasi yang ada di ketiga pulau relatif sama, yaitu beberapa jenis rerumputan khas pantai, pohon kelapa dan cemara laut.

\section{KESIMPULAN}

Kawasan Kapoposang merupakan lokasi yang potensial untuk dikembangkan sebagai lokasi kegiatan wisata bahari berbasis konservasi dan wisata minat khusus berdasarkan potensinya yang (1) memiliki keragaan sumber daya alam khas ekosistem pulau-pulau kecil; (2) memiliki masyarakat dengan kearifan lokal dan tingkat pemahaman kesadaran atas lingkungan yang tinggi; dan (3) merupakan kawasan pulau-pulau kecil yang potensial dengan sumber daya kelautan, perikanan, jasajasa lingkungan, serta telah memiliki rencana zonasi pulau-pulau kecil.

\section{DAFTAR PUSTAKA}

Berhimpon, S., Masengi, K.W.A., Emor,D., Ompi, M., Pankie, P., Katuuk, E., Mamonto. 2007. Kajian Identifikasi Kawasan Konservasi Laut Daerah BelangKotabunan, Provinsi Sulawesi Utara. Jurnal Mitra Bahari. Vol. 1 No.2 April Juli 2007. ISSN 0216-4841. Program Mitra Bahari . Jakarta.

Departemen Kelautan dan Perikanan RI. 2009. Penyusunan Zonasi Pulau-pulau Kecil di Kabupaten Pangkajene Kepulauan. Jakarta.

2007. Laporan Akhir Model Pengembangan dan Valuasi Ekonomi Kawasan Wisata Bahari di Pulau-pulau Kecil. Jakarta.

2006. Wawasan Nusantara Melalui Pendekatan Kultural. Makalah disampaikan pada Pelatihan Tenaga Pendamping Desa Pesisir dan Pulaupulau Kecil. Malang, 8 Juli 2006.

2005. Laporan Akhir Pemanfaatan Potensi Jasa-jasa Kelautan Pulau-pulau Kecil Melalui Penetapan Kawasan Konservasi Laut. Jakarta.

Dinas Perikanan dan Kelautan Kabupaten Pangkajene Kepulauan. 2007. Profil Pulau-pulau Kecil Kabupaten Pangkajene Kepulauan. Pangkep.

Keputusan Menteri Kebudayaan dan Pariwisata No. KM.67/UM.001/MKP/2004 ttg Pedoman Umum Pengembangan Pariwisata di Pulau-pulau Kecil. 2004. Kementerian Kebudayaan dan Pariwisata. Jakarta.

Kusumastanto, T. pulau-pulau-http://tridoyo. blogspot.com/2007/09/pembangunan pulau-pulau kecil.html. (diakses tgl 9 Juli 2010).

Pitana, I.G., dan Gayatri. P. 2005. Sosiologi Pariwisata. ISBN 979-731-700-5. Penerbit Andi. Yogyakarta.

Rais, J., dkk. 2004. Menata Ruang Laut Terpadu. ISBN 979-408-526-X. PT. Pradnya Paramita. Jakarta.

Retraubun, A.S.W. 2006. Pemberdayaan Pulau-pulau Kecil dalam Peningkatan Kesejahteraan Masyarakat. Makalah disampaikan pada Acara Peresmian Program Pemberdayaan Ekonomi Masyarakat Pesisir Provinsi Maluku, Kepulauan Aru, 28-29 Maret 2006.

2005. Pengelolaan Pulau-pulau Kecil di Indonesia. Makalah disampaikan pada Pelatihan Pelatih untuk Pelatih Pengelolaan Wilayah Pesisir Terpadu. Bogor, 8-9 Maret 2005.

2003. Kebijakan dan Strategi Pemberdayaan Pulau-pulau Kecil. Makalah disampaikan pada Rapat Koordinasi Penanganan Terpadu Program Pembangunan. Jakarta, 17-18 Desember 2003.

Undang-Undang RI No. 27/2007 ttg PengeloIaan Wilayah Pesisir dan Pulau-Pulau Kecil. Jakarta.

Yusuf, M. 2008. Pengembangan dan Pembinaan Daerah Perlindungan Laut Berbasis Masyarakat di Pulau Barrang Cadi. Jurnal Mitra Bahari. Vol. 2 No.3 Agustus -Oktober 2008. ISSN 0216-4841. Program Mitra Bahari. Jakarta. 